\title{
Influence of plant density and hilling on yield and profitability of arrowroot ${ }^{1}$
}

\author{
Leandro Bassi Moreno ${ }^{2}$, Elissandra Pacito Torales ${ }^{3}$, \\ Diego Menani Heid², Nestor Antonio Heredia Zárate ${ }^{2}$, Marianne Sales Abrão ${ }^{2}$
}

\section{ABSTRACT}

The global production of arrowroot is minimal, and this may be partially associated to the lack of standardized agronomic techniques for its commercial cultivation. This study aimed to assess the yield and profitability of arrowroot plants ('Comum' cultivar) grown using different plant spacings in the cropping row $(20 \mathrm{~cm}, 25 \mathrm{~cm}, 30 \mathrm{~cm}$ and $35 \mathrm{~cm})$ and a varying number of hilling applications $(0,1$ and 2$)$. The treatments were arranged in a $4 \times 3$ factorial scheme, in a randomized experimental block design, with six replications. After harvesting, the fresh and dry matter yields of leaves, rhizomes and roots were determined. Production costs and gross and net incomes were also calculated. The highest yields for fresh leaves $\left(8.75 \mathrm{tha}^{-1}\right)$, rhizomes $\left(32.92 \mathrm{tha}^{-1}\right)$ and roots $\left(8.45 \mathrm{t} \mathrm{ha}^{-1}\right)$ were obtained with a plant spacing of $20 \mathrm{~cm}$. No interaction between the factors, neither significant differences for the use or not of hilling, were observed on the analyzed variables. The costs per hectare ranged from BRL 8,488.83 (35 cm without hilling) to BRL 10,376.23 (20 cm with two hillings). The highest yields and gross and net incomes were obtained with the spacing of $20 \mathrm{~cm}$ between plants.

KEYWORDS: Maranta arundinacea; unconventional crops; production costs.

\section{INTRODUCTION}

Arrowroot (Maranta arundinaceae L.), which belongs to the Marantaceae family, is an erect herbaceous plant (Kinupp \& Lorenzi 2014), 0.60-1.20 m tall, with long pointed leaves. A white thickening agent (tapioca starch or gum) with good digestibility is extracted from its rhizomes and used for cooking. It is an unconventional vegetable that used to be widely cultivated by family farmers in some regions, but over time has lost ground to other agricultural crops (Silveira et al. 2013).

\section{RESUMO}

Densidade de plantas e amontoas

influenciando a produtividade e rentabilidade de araruta

A produção mundial de araruta é pequena, em parte devido à falta de técnicas agronômicas padronizadas para o seu cultivo comercial. Objetivou-se avaliar a produtividade e rentabilidade de plantas de araruta (cultivar 'Comum') cultivadas em diferentes espaçamentos entre plantas na fileira $(20 \mathrm{~cm}, 25 \mathrm{~cm}, 30 \mathrm{~cm}$ e $35 \mathrm{~cm})$ e sob números variáveis de amontoas $(0,1$ e 2). Os tratamentos foram arranjados em esquema fatorial $4 \times 3$, em delineamento experimental de blocos casualizados, com seis repetições. Após a colheita, foram determinadas as produtividades de massa fresca e seca de folhas, rizomas e raízes. Calcularam-se, também, os custos de produção e as rendas bruta e líquida. As maiores produções frescas de folhas $\left(8,75\right.$ tha $\left.^{-1}\right)$, rizomas $\left(32,92\right.$ tha $\left.^{-1}\right)$ e raízes $\left(8,45\right.$ tha $\left.^{-1}\right)$ foram obtidas no espaçamento de $20 \mathrm{~cm}$. Não houve interação entre os fatores, e nem diferenças significativas para o uso ou não de amontoa foram observadas nas variáveis analisadas. Os custos por hectare variaram de $\mathrm{R} \$ 8.488,83$ (35 cm sem amontoa) a R \$ 10.376,23 (20 cm com duas amontoas). As maiores produtividades e rendas bruta e líquida foram obtidas com o espaçamento de $20 \mathrm{~cm}$ entre plantas.

PALAVRAS-CHAVE: Maranta arundinacea; cultivos não convencionais; custos de produção.

The recovery of arrowroot is vital to the Brazilian agriculture, particularly family farming, due to its hardiness, high market value and the fact that it does not require sophisticated technologies (Vieira et al. 2015).

According to Harmayani et al. (2011), the nutritional composition of arrowroot starch is water $(11.9 \%)$, ash $(0.58 \%)$, amylose $(25.9 \%)$, protein $(0.14 \%)$, fat $(0.84 \%)$, insoluble fiber $(8.7 \%)$ and soluble fiber $(5.0 \%)$, and its flour is a potential source of prebiotics.

The price of arrowroot starch in the domestic market varies from BRL 15.00 to BRL 20.00 per kg,

1. Manuscript received in Aug./2017 and accepted for publication in Dec./2017 (http://dx.doi.org/10.1590/1983-40632017v4748643).

2. Universidade Federal da Grande Dourados, Faculdade de Ciências Agrárias, Departamento de Produção Vegetal, Dourados, MS, Brasil.E-mails: leandrobmoreno@hotmail.com,diegoheid@hotmail.com,nestorzarate@ufgd.edu.br, marianne.abrao@hotmail.com.

3. Universidade Federal da Grande Dourados, Faculdade de Ciências Biológicas, Departamento de Biologia Geral, Dourados, MS, Brasil. E-mail: ninapacito@hotmail.com. 
reaching higher prices in the international market (450 g cost around USD 22.19) (EBDA 2013).

Studying the profitability and monitoring costs are essential in agronomics (Melo et al. 2009), where the costs involved in the crop production may be decisive for the success or failure of rural farmers, since profitability consists of subtracting costs from income to determine the net profit (Silva et al. 2001).

Important information on crop treatments for the arrowroot production includes the plant population, which aims to maintain or increase crop yield (Terra et al. 2010) and may be adjusted by changing the spacing between rows and increasing plant density along the rows according to an ideal population, since intrinsic genotype traits and environmental conditions may interfere in the results (Ludwig et al. 2011).

Another management technique in vegetable crops is hilling, which involves piling up soil around the base of the plant and covering part of the base of the stem and/or root of the plant (Peche Filho 2008). The main advantages of hilling include eliminating weeds, draining excess irrigation or rainwater, promoting root growth and protecting the edible roots, rhizomes and stems of some plants from direct sunlight (Heredia Zárate \& Vieira 2005).

In arrowroot, cultivation may be performed with two or three rows between plants (Gomes 2010, Heredia Zárate \& Vieira 2005). Thus, some agronomic improvements may be achieved due to the better use of the area by changing the spacing between plants in the cropping row.

This study aimed to determine the agronomic yield and profitability of arrowroot plants ('Comum' cultivar) grown on different plant spacings in the cropping rows, and varying the number of hilling applications.

\section{MATERIAL AND METHODS}

The study was conducted in an experimental area of the Universidade Federal da Grande Dourados, in Dourados, Mato Grosso do Sul state, Brazil (22 ${ }^{\circ} 11^{\prime} 43.7^{\prime \prime} \mathrm{S}, 54^{\circ} 56^{\prime} 08.5^{\prime \prime} \mathrm{W}$ and $458 \mathrm{~m}$ of altitude). The trial growing season extended from October 2014 to August 2015. The climate in the region is classified as humid mesothermal (type Am) (Alvarez et al. 2013), with average annual rainfall of more than $1,500 \mathrm{~mm}$ and less than $60 \mathrm{~mm}$ in the driest month. The soil is classified as a very clayey Distroferric Red Latosol (Oxisol) (Embrapa 2013) and its analysis exhibited a $\mathrm{pH}\left(\mathrm{H}_{2} \mathrm{O}\right)=6.1$; $\mathrm{P}($ Melhich $)=29 \mathrm{mg} \mathrm{dm}^{-3} ; \mathrm{K}=1.1 \mathrm{mmol}_{\mathrm{c}} \mathrm{dm}^{-3} ; \mathrm{Ca}=$ $50 \mathrm{mmol}_{\mathrm{c}} \mathrm{dm}^{-3} ; \mathrm{Mg}=18 \mathrm{mmol}_{\mathrm{c}} \mathrm{dm}^{-3}$; cation exchange capacity $=101 \mathrm{mmol}_{\mathrm{c}} \mathrm{dm}^{-3}$; sum of base cations $=$ $69.1 \mathrm{mmol} \mathrm{dm}^{-3}$; base saturation $=69 \%$.

The treatments were arranged in a $4 \times 3$ factorial, designed in a randomized complete block, with six replications. The first treatment factor was represented by the plant spacing in each cropping row: $20.0 \mathrm{~cm}(99,000$ plants ha-1 $), 25.0 \mathrm{~cm}(79,200$ plants ha-1 $), 30.0 \mathrm{~cm}\left(66,000\right.$ plants ha- $\left.{ }^{-1}\right)$ and $35.0 \mathrm{~cm}$ (56,571 plants ha $\left.{ }^{-1}\right)$; all arranged with $33 \mathrm{~cm}$ between rows. The second treatment factor was the number of hilling applications $(0,1$ and 2$)$.

The land was prepared by plowing and harrowing and the beds were subsequently raised using a ridge plow. The total area of each plot was $4.2 \mathrm{~m}^{2}$ (1.5 m wide and $2.8 \mathrm{~m}$ long) and the study area measured $2.8 \mathrm{~m}^{2}(1.0 \mathrm{~m}$ wide and $2.8 \mathrm{~m}$ long).

Rhizomes of arrowroot plants ('Comum' cultivar) from experiments conducted in the previous year were selected for planting. The plants of this cultivar are low (60 cm high), with clear rhizomes, conical-elongated or spindle-shaped, covered by scales, and can reach up to $30 \mathrm{~cm}$ in length (Leonel \& Cereda 2002). The rhizomes were classified into sizes, maintaining an average weight of approximately $10 \mathrm{~g}$ per seedling, and visually selected by removing those that appeared damaged. Three furrows (rows) were made in the plots, measuring $5 \mathrm{~cm}$ wide and $5 \mathrm{~cm}$ deep and spaced $33 \mathrm{~cm}$ apart. The rhizomes were planted vertically with the buds facing upwards, in the different plant spacings under study.

Sprinkler irrigation was used in order to maintain a $70 \%$ field capacity. Initially, irrigation was performed daily up to 60 days after planting (DAP), and then every two days up to 180 DAP, every three days up to 270 DAP and, finally, once a week until harvesting. Weeds were controlled between rows using a hoe and manually within rows. No pest infestations or diseases that required the use of pesticides were detected. Hilling was performed at 40 DAP (for one hilling) and 40 and 70 DAP (for two hillings), using hoes to turn over the soil adjacent to the plant and cover the base of the pseudostem.

The arrowroot plants were harvested at 296 DAP, when more than $50 \%$ of the leaves were brown and wilted, subsequently turning white and 'curling', until completely touching the ground. At this point, 
yield was calculated for the fresh and dry weight of leaves, rhizomes and roots (dry weight was obtained after drying the material in a forced-air oven for $96 \mathrm{~h}$, at $60^{\circ} \mathrm{C} \pm 2{ }^{\circ} \mathrm{C}$ ).

The yield data for the different response variables were submitted to analysis of variance. When significance for treatments was observed by the $\mathrm{F}$ test at $5 \%$, a regression analysis was applied as a function of plant spacing and the Tukey test (5\%) for comparing the hilling level means.

The production costs were calculated by adapting the tables for 'Comum' arrowroot plants presented by Abrão (2016), as well as those for 'Amarela de Carandaí' Peruvian carrots reported by Torales et al. (2014) and Heid et al. (2015).

In order to determine the seedlings cost, an additional $5 \%$ was added to the number of seedlings planted (to account for any losses due to poor germination, damaged seedlings, survival percentage, rotten and defective seedlings) and then multiplied by the average seedling weight $(16.6 \mathrm{~g})$. The amount used $\left(\mathrm{kg} \mathrm{ha}^{-1}\right)$ was multiplied by the seedlings value, corresponding to BRL $1.10 \mathrm{~kg}^{-1}$ (Abrão 2016).

Labor costs were calculated by multiplying the number of man-days (MD) required for each activity by the daily amount paid (BRL 45.00 MD) in Dourados, for temporary labor during the study period.

The machinery (irrigation pump and tractor) cost was calculated by recording the number of hours needed to carry out the work required for each operation, which was converted into the machine rate per hectare and multiplied by the amount per hour for each piece of equipment, namely the irrigation pump (BRL $10.00 \mathrm{~h}^{-1}$ ) and tractor (BRL $60.00 \mathrm{~h}^{-1}$ ).

The production costs and gross and net incomes were estimated considering the fresh weight yield of arrowroot rhizomes. Net income was calculated by subtracting the production cost per hectare cultivated from gross income.

\section{RESULTS AND DISCUSSION}

The fresh and dry mass of arrowroot leaves, rhizomes and roots were not significantly influenced by the interaction between the factors under study (plant spacing and hilling), but were affected by plant spacing alone. The number of hilling applications did not influence any of the variables assessed. These results may be attributed to variations in the translocation of reserve photosynthates in the plants, which were also observed by Heredia Zárate et al. (2005), when assessing rhizome yield in taro clones cultivated under different numbers of hilling.

Leaf fresh and dry mass decreased linearly with increased plant spacing (Figure 1). The maximum values recorded were $8.75 \mathrm{t} \mathrm{ha}^{-1}$ for fresh weight and $4.03 \mathrm{t} \mathrm{ha}^{-1}$ for dry weight, obtained for a plant spacing of $20 \mathrm{~cm}$, reflecting an increase of $4.08 \mathrm{t} \mathrm{ha}^{-1}(87.37 \%)$ and $1.92 \mathrm{t} \mathrm{ha}^{-1}(109.90 \%)$, respectively, in relation to the spacing of $35 \mathrm{~cm}$, which produced the lowest means $\left(4.67 \mathrm{t} \mathrm{ha}^{-1}\right.$ and $1.92 \mathrm{t} \mathrm{ha}^{-1}$, respectively).

This increase in the fresh and dry weight values may be attributed to both the higher number of plants per area under the smallest spacing used $(20.0 \mathrm{~cm})$ and their more equidistant distribution. This ensures a more efficient use of sunlight, water and nutrients, faster coverage of the available space and better weed control (Embrapa 2010).

The plant spacing of $20 \mathrm{~cm}$ also produced the highest rhizome fresh and dry mass (Figure 2), with maximum values of $32.92 \mathrm{tha}^{-1}$ and $9.67 \mathrm{tha}^{-1}$, respectively, exceeding the lowest values recorded at $35 \mathrm{~cm}\left(19.72 \mathrm{t} \mathrm{ha}^{-1}\right.$ and $\left.5.87 \mathrm{tha}^{-1}\right)$ by $13.20 \mathrm{t} \mathrm{ha}^{-1}$ $(66.94 \%)$ and $3.80 \mathrm{t} \mathrm{ha}^{-1}(64.74 \%)$. The increase of plant population as a function of the reduction in plant spacing in the rows provided a higher rhizome yield, which also increased the leaf fresh and dry mass (Figure 1) through a better radiation absorption without competition, a decisive variable in plant growth (Pereira et al. 2008).

The yield results for leaves and rhizomes corroborate those reported by Fontes et al. (2012), who assessed the potato yield in response to variations in spacing between plants in the crop rows. They also found that the commercial yield per area decreased

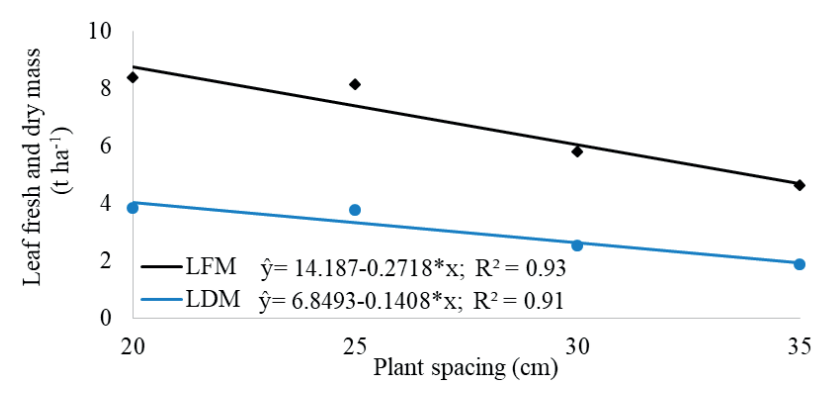

Figure 1. Leaf fresh (LFM) and dry mass (LDM) of arrowroot plants ('Comum' cultivar), as a function of plant spacing, in the cropping rows. 
exponentially with the increased plant spacing, i.e., with the decrease in the plant population, such as observed here.

Root fresh and dry weight showed the same trend as the values recorded for rhizomes and leaves, whereby yield declined linearly as the plant spacing increased (Figure 3 ). The maximum values observed were $8.45 \mathrm{t} \mathrm{ha}^{-1}$ (fresh weight) and $3.51 \mathrm{t} \mathrm{ha}^{-1}$ (dry weight) at $20 \mathrm{~cm}$, an increase of $4.56 \mathrm{tha}^{-1}(117.22 \%)$ and $2.07 \mathrm{tha}^{-1}(143.75 \%)$, respectively, in relation to the $35 \mathrm{~cm}$ plant spacing, which obtained the lowest yields (3.89 $\mathrm{t} \mathrm{ha}^{-1}$ and $\left.1.44 \mathrm{t} \mathrm{ha}^{-1}\right)$.

These results are consistent with those observed by Aguiar et al. (2011), who studied the effect of population density on the yield of sweet cassava roots and found that the highest population density used $\left(20,000\right.$ plants ha $\left.{ }^{-1}\right)$ produced the highest total root yield, but lower commercial root yields. By contrast, the authors observed an increase in commercial root yield at lower plant densities, in relation to the total production. Because arrowroot may be sold fresh or industrially processed to extract

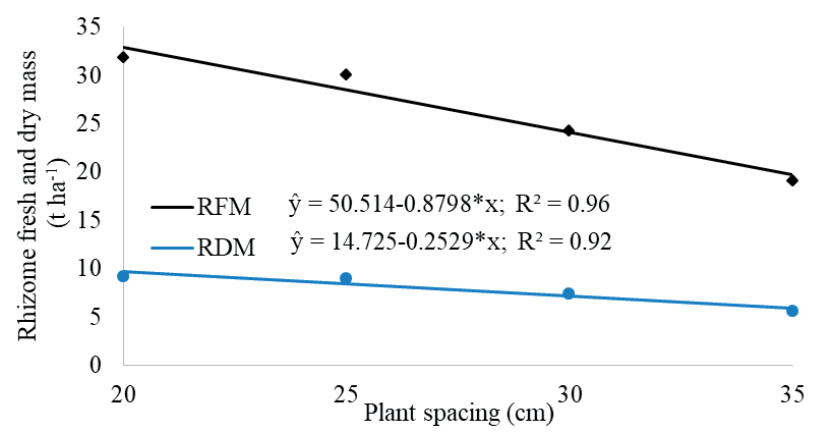

Figure 2. Rhizome fresh (RFM) and dry mass (RDM) of arrowroot plants ('Comum' cultivar), as a function of plant spacing, in the cropping rows.

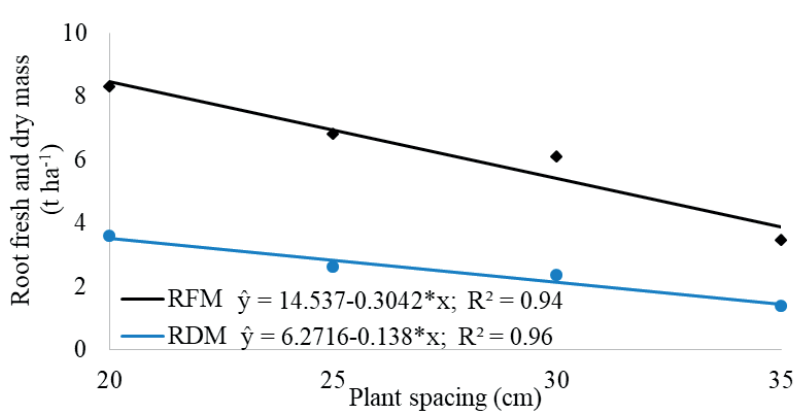

Figure 3. Root fresh (RFM) and dry mass (RDM) of arrowroot plants ('Comum' cultivar), as a function of plant spacing, in the cropping rows. starch, there is no need to separate the rhizomes according to their commercial viability, i.e., aiming only at increasing the amount of production.

Torales et al. (2015) studied the Peruvian carrot, also considered a tuber, under two plant spacings $(20 \mathrm{~cm}$ and $25 \mathrm{~cm})$ and reported different results from those observed here, whereby the best leaf $\left(0.73 \mathrm{t} \mathrm{ha}^{-1}\right)$ and commercial root dry weights $\left(13.00 \mathrm{t} \mathrm{ha}^{-1}\right)$ were obtained at the smallest spacing $(25 \mathrm{~cm})$, which was attributed to less competition between the plants. By contrast, Rós \& São João (2016) assessed the agronomic performance of cassava and sweet potato plants and found no significant differences for root dry weight.

According to Taiz \& Zeiger (2013), cultivation with larger plant populations reduces yield due to the shading of basal leaves, which receive less sunlight. However, this was not observed in the present study, where the best results were obtained with the largest plant populations. This may be related to the arrowroot architecture, an erect herbaceous plant (Kinupp \& Lorenzi 2014) with little shading, among other factors.

None of the variables assessed were significantly influenced by hilling, with means of $6.68 \mathrm{t} \mathrm{ha}^{-1}, 6.17 \mathrm{t} \mathrm{ha}^{-1}$ and $26.29 \mathrm{t} \mathrm{ha}^{-1}$, respectively for leaf, root and rhizome fresh mass, and $3.00 \mathrm{t} \mathrm{ha}^{-1}$, $2.49 \mathrm{t} \mathrm{ha}^{-1}$ and $7.82 \mathrm{t} \mathrm{ha}^{-1}$ for dry mass.

The estimated cost of growing 1.0 ha of 'Comum' arrowroot, using the treatments under study (Table 1), varied in BRL 1,025.12, corresponding to the plant spacings of $35.0 \mathrm{~cm}$ (BRL 8,488.83) and $20 \mathrm{~cm}$ (BRL 10,376.23).

Variable costs ranged from $66.89 \%$ to $68.64 \%$, respectively for $35 \mathrm{~cm}$ and $20 \mathrm{~cm}$ spacings. Labor costs were $41.63 \%$ and $42.38 \%$ (BRL 4,140.00 and BRL 3,780.00) for $20 \mathrm{~cm}$ and $35 \mathrm{~cm}$ plant spacings, respectively. Raw materials (seedlings) accounted for $7.47 \%$ of the total cost (BRL 666.43) for the $35 \mathrm{~cm}$ plant spacing and $11.73 \%$ (BRL 1,166.32) for $20 \mathrm{~cm}$ (Table 1).

Expenditure for machinery (BRL 1,520.00) varied from $15.28 \%$ to $17.04 \%$ of the total cost at $20 \mathrm{~cm}$ and $35 \mathrm{~cm}$, respectively (Table 1). Fixed costs were the same for all the treatments (BRL 1,710.00 $\mathrm{ha}^{-1}$ ), ranging from $17.20 \%$ to $19.17 \%(20 \mathrm{~cm}$ and $35 \mathrm{~cm})$.

Considering the average rhizome yield obtained for each treatment (Figure 4), average production costs (Table 1) and estimated gross and 
net income (Figure 5), 'Comum' cultivar arrowroot plants grown with spacing of $20 \mathrm{~cm}$ provided the highest yield (33.41 $\mathrm{t} \mathrm{ha}^{-1}$ ) and gross income (BRL $36,751.00)$, in relation to the other treatments.

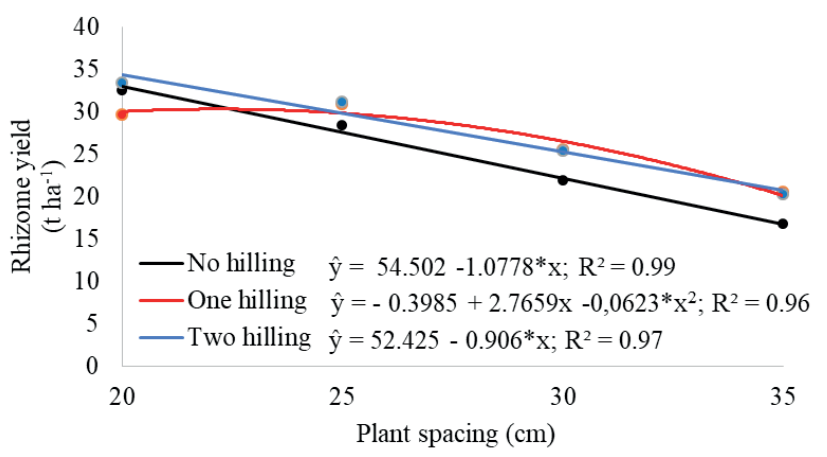

Figure 4. Rhizome yield per hectare of arrowroot ('Comum' cultivar), as a function of plant spacing in the cropping row, for different numbers of hillings.
The highest net income recorded was BRL 26,374.77 for two hilling applications and plant spacing of $20.0 \mathrm{~cm}$, with a difference of BRL $16,471.60$, in relation to the lowest amount (BRL

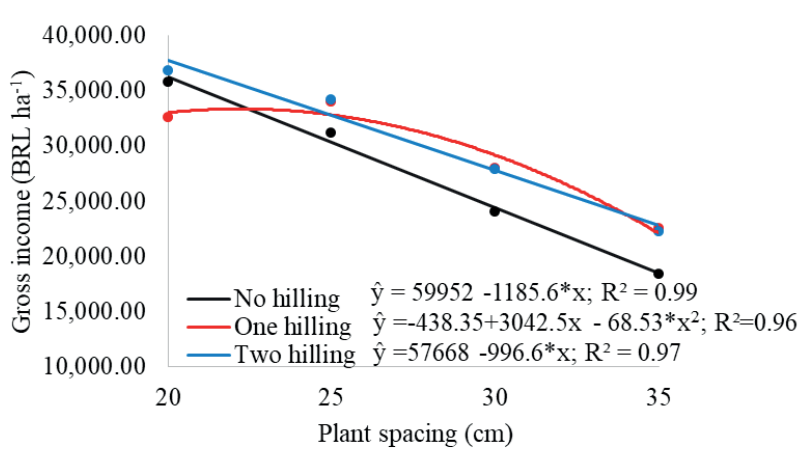

Figure 5. Gross income per hectare of arrowroot ('Comum' cultivar), as a function of plant spacing in the cropping row, for different numbers of hillings.

Table 1. Average production costs for one hectare (BRL) of arrowroot plants ('Comum' cultivar) grown under different plant spacings and hilling applications.

\begin{tabular}{|c|c|c|c|c|c|c|c|c|}
\hline \multirow{2}{*}{ Cost components } & \multicolumn{8}{|c|}{ Plant spacing $(\mathrm{cm})$} \\
\hline & \multicolumn{2}{|c|}{20} & \multicolumn{2}{|c|}{25} & \multicolumn{2}{|c|}{30} & \multicolumn{2}{|c|}{35} \\
\hline 1. Variable Costs & Amount $(\mathrm{kg})$ & Cost (BRL) & Amount (kg) & Cost (BRL) & Amount $(\mathrm{kg})$ & Cost (BRL) & Amount (kg) & Cost (BRL) \\
\hline \multicolumn{9}{|l|}{ Raw Materials } \\
\hline Seedlings $^{1}$ & $1,060.29$ & $1,166.32$ & 807.84 & 933.05 & 706.86 & 777.54 & 605.85 & 666.43 \\
\hline \multicolumn{9}{|l|}{ Labor } \\
\hline Seedling preparation & $8.00 \mathrm{MD}$ & 360.00 & $8.00 \mathrm{MD}$ & 360.00 & $6.00 \mathrm{MD}$ & 270.00 & $6.00 \mathrm{MD}$ & 270.00 \\
\hline Planting & $16.00 \mathrm{MD}$ & 720.00 & $14.00 \mathrm{MD}$ & 630.00 & $12.00 \mathrm{MD}$ & 540.00 & $10.00 \mathrm{MD}$ & 450.00 \\
\hline Irrigation & $10.00 \mathrm{MD}$ & 450.00 & $10.00 \mathrm{MD}$ & 450.00 & $10.00 \mathrm{MD}$ & 450.00 & $10.00 \mathrm{MD}$ & 450.00 \\
\hline Weeding & $20.00 \mathrm{MD}$ & 900.00 & $20.00 \mathrm{MD}$ & 900.00 & $20.00 \mathrm{MD}$ & 900.00 & $20.00 \mathrm{MD}$ & 900.00 \\
\hline Hilling & $8.00 \mathrm{MD}$ & 360.00 & $8.00 \mathrm{MD}$ & 360.00 & $8.00 \mathrm{MD}$ & 360.00 & $8.00 \mathrm{MD}$ & 360.00 \\
\hline Harvesting & $30.00 \mathrm{MD}$ & $1,350.00$ & $30.00 \mathrm{MD}$ & $1,350.00$ & $30.00 \mathrm{MD}$ & $1,350.00$ & $30.00 \mathrm{MD}$ & $1,350.00$ \\
\hline \multicolumn{9}{|l|}{ Machinery } \\
\hline Irrigation pump & $80.00 \mathrm{~h}$ & 800.00 & $80.00 \mathrm{~h}$ & 800.00 & $80.00 \mathrm{~h}$ & 800.00 & $80.00 \mathrm{~h}$ & 800.00 \\
\hline Tractor - preparation & $8.00 \mathrm{~h}$ & 480.00 & $8.00 \mathrm{~h}$ & 480.00 & $8.00 \mathrm{~h}$ & 480.00 & $8.00 \mathrm{~h}$ & 480.00 \\
\hline Tractor - harvest & $4.00 \mathrm{~h}$ & 240.00 & $4.00 \mathrm{~h}$ & 240.00 & $4.00 \mathrm{~h}$ & 240.00 & $4.00 \mathrm{~h}$ & 240.00 \\
\hline Subtotal 1 (BRL) & & $6,826.32$ & & $6,503.05$ & & $6,167.54$ & & $5,966.43$ \\
\hline \multicolumn{9}{|l|}{ 2. Fixed Costs } \\
\hline Buildings and other structures & 240 days & 360.00 & 240 days & 360.00 & 240 days & 360.00 & 240 days & 360.00 \\
\hline Opportunity cost of land ${ }^{2}$ & $1.00 \mathrm{ha}$ & $1,350.00$ & $1.00 \mathrm{ha}$ & $1,350.00$ & $1.00 \mathrm{ha}$ & $1,350.00$ & $1.00 \mathrm{ha}$ & $1,350.00$ \\
\hline Subtotal 2 (BRL) & & $1,710.00$ & & $1,710.00$ & & $1,710.00$ & & $1,710.00$ \\
\hline \multicolumn{9}{|l|}{ 3. Other Costs } \\
\hline Unforeseen events (10 \% of subtotal 1$)$ & & 677.08 & & 645.86 & & 613.05 & & 593.47 \\
\hline Administration $(5 \%$ of subtotal 1$)$ & & 338.54 & & 322.93 & & 306.52 & & 296.73 \\
\hline Subtotal 3 & & $1,015.62$ & & 968.79 & & 919.57 & & 890.20 \\
\hline Total & & $9,551.94$ & & $9,181.84$ & & $8,797.11$ & & $8,566.63$ \\
\hline Quarterly interest $(0.46 \%)^{3}$ & 9 months & 393.15 & & 378.29 & & 362.66 & & 353.34 \\
\hline Overall total ha $^{-1}$ & & $9,945.09$ & & $9,560.13$ & & $9,159.77$ & & $8,919.97$ \\
\hline
\end{tabular}




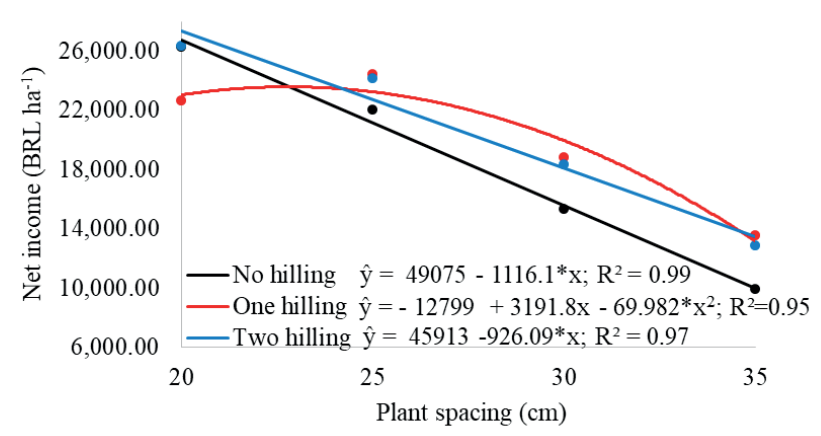

Figure 6. Net income per hectare of arrowroot ('Comum' cultivar), as a function of plant spacing in the cropping row, for number of hillings.

9,903.17), obtained without hilling at $35 \mathrm{~cm}$ (Figure 6). Abrão (2016) studied the agronomic yield of 'Comum' arrowroot plants grown at different plant densities $(17.5 \mathrm{~cm}, 20.0 \mathrm{~cm}, 22.5 \mathrm{~cm}$ and $25.0 \mathrm{~cm}$ between plants) in chicken manure and obtained the highest net income (BRL 12,997.65) without chicken manure and plant spacing of $22.5 \mathrm{~cm}, 50.82 \%$ lower than the highest net income recorded here.

\section{CONCLUSION}

The use of hilling does not increase the yield of rhizomes in arrowroot ('Comum' cultivar). In this cultivar, the highest yield and gross and net incomes are provided when the plants are grown on the spacing of $20 \mathrm{~cm}$ in the cropping rows.

\section{ACKNOWLEDGMENTS}

The autors are grateful to the Fundação de Apoio ao Desenvolvimento do Ensino, Ciência e Tecnologia do Estado de Mato Grosso do Sul (Fundect) and Coordenação de Aperfeiçoamento de Pessoal de Nível Superior (Capes), for financially supporting this research.

\section{REFERENCES}

ABRÃO, M. S. Produtividade agroeconômica de plantas de araruta 'Comum' cultivadas com diferentes densidades de plantio e camas de frango. 2016. 27 f. Dissertação (Mestrado em Agronomia) - Universidade Federal da Grande Dourados, Dourados, 2016.

AGUIAR, E. B. et al. Efeito da densidade populacional e época de colheita na produção de raízes de mandioca de mesa. Bragantia, v. 70, n. 3, p. 561-569, 2011.
ALVAREZ, C. L. et al. Köppen's climate classification map of Brazil. Meteorologische Zeitschrift, v. 22, n. 6, p. 711-728, 2013.

EMPRESA BAIANA DE DESENVOLVIMENTO AGRÍCOLA S. A. (EBDA). EBDA busca resgatar cultura da araruta em Cruz das Almas. 2013. Available at: $<$ http:// www.ebda.ba.gov.br/ebda-resgata-a-cultura-da-ararutaem-cruz-das-almas $>$. Access on: 25 Jun. 2017.

EMPRESA BRASILEIRA DE PESQUISA AGROPECUÁRIA (Embrapa). Sistema brasileiro de classificação de solos. 3. ed. Rio de Janeiro: Embrapa Produção de Informação, 2013.

EMPRESA BRASILEIRA DE PESQUISA AGROPECUÁRIA (Embrapa). Sistema de produção do milho. 6. ed. 2010. Available at: <http://www.cnpms. embrapa.br/publicacoes/milho_6_ed/manejomilho.htm>. Access on: 01 Aug. 2017.

FONTES, P. C. R. et al. Produção classificada de batata em resposta ao espaçamento e critério de recomendação da adubação. Bioscience Journal, v. 28, n. 3, p. 404-412, 2012.

HARMAYANI, E. et al. Effect of arrowroot (Maranta arundinacea $\mathrm{L}$.) diet on the selected bacterial population and chemical properties of caecal digesta of Sprague Dawley rats. International Research Journal of Microbiology, v. 2, n. 8, p. 278-284, 2011.

HEID, D. M. et al. Produtividade agroeconômica de mandioquinha-salsa em resposta à adição de cama de frango no solo. Revista Semina, v. 36, n. 3, p. 1835-1850, 2015.

HEREDIA ZÁRATE, N. A.; VIEIRA, M. do C. Produção da araruta comum proveniente de três tipos de propágulos. Ciência e Agrotecnologia, v. 29, n. 5, p. 995-1000, 2005.

KINUPP, V. F.; LORENZI, H. Plantas alimentícias não convencionais (PNAC) no Brasil. São Paulo: Instituto Plantarum, 2014.

LEONEL, M.; CEREDA, M. P. Caracterização físicoquímica de algumas tuberosas-amiláceas. Ciência e Tecnologia de Alimentos, v. 22, n. 1, p. 65-69, 2002.

LUDWIG, M. P. et al. Populações de plantas na cultura da soja em cultivares convencionais e Roundup Ready ${ }^{\mathrm{TM}}$. Revista Ceres, v. 58, n. 3, p. 305-313, 2011.

MELO, A. S. et al. Custo e rentabilidade na produção de batata-doce nos perímetros irrigados de Itabaiana, Sergipe. Pesquisa Agropecuária Tropical, v. 39, n. 2, p. 119-123, 2009.

PECHE FILHO, A. Amontoa antecipada: uma operação importante no sistema planta forte batata. 2008. Available at: $<\mathrm{http}: / / w w w . a b b a b a t a t a b r a s i l e i r a . c o m . b r / r e v i s t a 10 \_019$. htm>. Access on: 24 Jul. 2014. 
PEREIRA, A. P. et al. Potato potential yield based on climatic elements and cultivar characteristics. Bragantia, v. 67, n. 2, p. 327-334, 2008.

ROS, A. B.; SÃO JOÃO, R. E. Desempenho agronômico e uso eficiente da terra em arranjos de plantas de mandioca e batata-doce. Revista Ceres, v. 63, n. 4, p. 517-522, 2016.

SILVA, V. et al. Indicadores de competitividade internacional dos produtos agrícolas e agroindustriais brasileiros: 1986-1998. Revista do Instituto de Economia Agrícola, v. 48, n. 1, p. 67-87, 2001.

SILVEIRA, J. R. S. et al. Resgate da cultura da araruta junto aos agricultores familiares no território do Recôncavo da Bahia. Cadernos de Agroecologia, v. 8, n. 2, p. 1-5, 2013.
TAIZ, L.; ZEIGER, E. Fisiologia vegetal. 5. ed. Porto Alegre: Artmed, 2013.

TERRA, T. G. R. et al. Desenvolvimento e produtividade de sorgo em função de diferentes densidades de plantas. Bioscience Journal, v. 26, n. 2, p. 208-215, 2010.

TORALES, E. P. et al. Influência da cama de frango e de espaçamentos entre plantas na produtividade agroeconômica de mandioquinha-salsa. Revista Ceres, v. 61, n. 2, p. 162-171, 2014.

TORALES, E. P. et al. Produtividade da mandioquinhasalsa em resposta aos espaçamentos entre plantas e peso de mudas. Bioscience Jounal, v. 31, n. 2, p. 433-444, 2015.

VIEIRA, J. C. B. et al. Desempenho da araruta 'Viçosa' consorciada com crotalária. Revista Agrária, v. 10, n. 4, p. 518-524, 2015. 